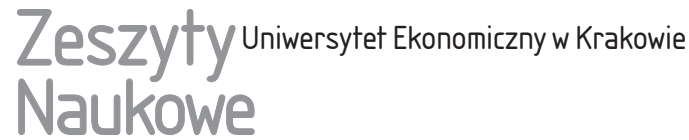

\section{Ethical Packaging - a Preliminary Study}

\begin{abstract}
The paper is a preliminary study of the concept of ethical packaging. Its main aim is to define the term "ethical packaging" and systemise a magnitude of the ethical issues surrounding packaging. A review of the literature on ethics and packaging enable the definition of such terms as business ethics, corporate ethics, Corporate Social Responsibility, Triple Bottom Line, ethical consumption, ethical eating, and sustainable packaging and provide the background for the discussion. To broaden the understanding of ethical packaging, a survey among 71 students from Maria Curie-Skłodowska University in Lublin, Poland, was conducted in 2016. The results of the survey contribute to the analysis of consumers' perception of ethical packaging.
\end{abstract}

Keywords: ethical packaging, sustainable packaging, functions of packaging, CSR, ethical consumption, ethical eating.

JEL Classification: Q01, Q56, D12.

\section{Introduction}

Ethical issues have taken on greater importance in the marketplace. Ethical behaviour together with the moral, emotional and social competences of owners, managers and employees of any organisation, seem to be a prerequisite for holding competitive advantage in the long run. The stakeholders of numerous organisations expect those making decisions to behave ethically. Since environ-

Aleksandra Kowalska, Maria Curie-Skłodowska University in Lublin, Faculty of Economics, Department of Quality and Knowledge Management, Maria Curie-Skłodowska Square 5, 20-031 Lublin, e-mail: aleksandra.kowalska@umcs.lublin.pl 
mental problems began to be discussed worldwide, governments, enterprises, consumers, various associations and unions have started paying more attention to environmentally sustainable development. This wide range of stakeholders has sought to mitigate the pressure on the environment resulting from continuous population and economic growth (de Medeiros, Ribeiro \& Cortimiglia 2014, pp. 76-86). In the face of more and more other problems like the food safety crisis, child labour, low-paid workers in developing countries, social inequality, human rights, animal rights and so on, it has occurred that it is not enough to be environmentally benign.

Ethical concerns, which include environmental concerns, have become an important issue. Environmental concerns may be prompted by the set of beliefs and values company management holds or from certain pressure exerted by the market. Management that respects the environment should raise a company's profile and its products (Cambra-Fierro, Hart \& Polo-Redondo 2008, pp. 645-656). A review of the most recent literature reveals an increasing number of terms and concepts dealing with ethical behaviours on the marketplace. These include business ethics, corporate ethics, Corporate Social Responsibility (CSR), Triple Bottom Line (TBL), ethical consumption, ethical eating and ethical packaging. And it is not only companies that are striving to be more ethical and environmentally conscious, but consumers as well. Packaging technologies and trends are developing as a response to consumer demands and production trends. Therefore, the question arises: what is ethical packaging? In spite of the magnitude of literature in the field of ethics and packaging, it is difficult to find a definition or a comprehensive elaboration.

The main aims of the paper are to define and discuss ethical packaging and to analyse and systematise the ethical issues surrounding it. The main hypothesis is that the idea of ethical packaging covers mainly the safety of packaging, the environmental impact of packaging, proper labelling and ethical marketing practices. A review of the literature and a consumer study will be the means by which the hypothesis is verified.

\section{Method}

The study is based on a survey of Polish students and on a review of recent literature in the field of ethics and packaging. It is a preliminary study, with a survey conducted among 71 students of Logistics (29), Management (16), and Law (26) at Maria Curie-Skłodowska University in Lublin, Poland, in February 2016. The respondents were 19-21 years of age. Men comprised approximately 
$45 \%$ of the group and women comprised about $55 \%$ of the group. The survey was conducted using only one open-ended question about students' perception of ethical packaging. The students were asked to provide their associations with the term "ethical packaging".

An initial systematic review of the literature was conducted with the search terms "ethical packaging", "packaging" and "ethics", "business ethics", "corporate ethics", CSR, TBL, "ethical consumption" and "ethical eating". The publications reviewed were accessed through international online research databases such as Wiley Online Library and EBSCOhost. The Polish literature on the subject was also reviewed.

\section{Ethical Issues in Economic Activity and Consumption - Background}

According to the online Cambridge Dictionary, ethics are "ideas and beliefs about what type of behaviour is morally right and wrong" while the adjective "ethical" means "relating to what is right or wrong"; "morally correct and good" (http://www.dictionary.cambridge.org, accessed: 18.02.2016). According to the online Encyclopedia of Philosophy, a synonym for ethics is "moral philosophy", or "the branch of philosophy that involves systematizing, defending, and recommending concepts of right and wrong behavior" (http://www.iep.utm.edu/ethics, accessed: 18.02.2016). The online Business Dictionary defines the term "ethical issue" as "a problem or situation that requires a person or organization to choose between alternatives that must be evaluated as right (ethical) or wrong (unethical)" (http://www.businessdictionary.com, accessed: 22.02.2016).

In the 1980s, R.E. Freeman defined ethics as a science of moral principles applied by decision-makers, a science of human rights and duties. In the 1990s, W. Kopaliński said that ethics was a moral science, moral philosophy, a certain ethical system; a set of norms and rules of behaviour recommended in current age and social background. At the same time, J. Teichman and K. C. Evans conceptualised ethics as moral research and studies, or a science of human duties that covered moral, legal and political duties. In 2002, R. W. Griffin claimed that ethical behaviour arose from generally accepted social norms. In 2011, J. Penc believed that ethics was a science of human rights and obligations, moral rights used in decision-making, and of a relationship nature (Mroziewski 2014, pp. 16-17). Table 1 presents a list of terms related to ethical behaviour in business, as discussed in the current literature. 
Table 1. The Terms Related to Ethical Behaviour in Business and Consumption

\begin{tabular}{|c|c|}
\hline Terms & Characteristics \\
\hline Business ethics & $\begin{array}{l}\text { Business ethics are moral principles that guide the way a business behaves. } \\
\text { The same principles that determine an individual's actions also apply to busi- } \\
\text { ness (http://businesscasestudies.co.uk, accessed: } 29.02 .2016 \text { ) }\end{array}$ \\
\hline Corporate ethics & $\begin{array}{l}\text { - stresses the focus of the firm and not the economy as a whole } \\
\text { - is implemented in a capitalist market economy, with competition and } \\
\text { individual freedom to make profit and utility, as the central elements } \\
\text { - ties business more closely to the public interest of peace } \\
\text { - motivates to take both efficient and responsible actions } \\
\text { - depends to a great extent on executives' morals } \\
\text { - encourages making profits ethically while protecting stakeholders' } \\
\text { interests (clients, suppliers, workers, employees, shareholders, creditors } \\
\text { and the public in general) (Steinmann \& Scherer 2000, pp. 148-192) }\end{array}$ \\
\hline $\begin{array}{l}\text { Corporate Social } \\
\text { Responsibility } \\
\text { (CSR) }\end{array}$ & $\begin{array}{l}\text { - a concept whereby companies integrate social and environmental concerns } \\
\text { in their business operations and in their interaction with their stakeholders } \\
\text { on a voluntary basis } \\
\text { - this responsibility is expressed towards employees and more generally } \\
\text { towards all the stakeholders affected by business and which in turn can } \\
\text { influence its success } \\
\text { - goes beyond fulfilling legal expectations and compliance (Promoting... } \\
\text { 2001, pp. 5-16) } \\
\text { - is based on ethics; being socially responsible means for individuals and } \\
\text { organisations to manifest ethical behaviour and to demonstrate sensitivity to } \\
\text { social, cultural, economic, and environmental issues; company activities for } \\
\text { social responsibility cover: fairness in relation to customers and employees, } \\
\text { good treatment of employees, supporting charities, protecting the environ- } \\
\text { ment, providing jobs (Soroka \& Mazurek-Kusiak 2014, pp. 117-122) }\end{array}$ \\
\hline $\begin{array}{l}\text { Triple Bottom } \\
\text { Line (TBL) }\end{array}$ & $\begin{array}{l}\text { - an accounting approach that expands the traditional reporting framework } \\
\text { to take into account social and environmental performance in addition to } \\
\text { financial performance (Elkington 1997) } \\
\text { - the success of a business depends on its performance in three fields: } \\
\text { financial, ecological and social (Chwistecka-Dudek 2014,pp. 11-54) }\end{array}$ \\
\hline $\begin{array}{l}\text { Ethical } \\
\text { consumption }\end{array}$ & $\begin{array}{l}\text { - addresses ethical issues as environmental sustainability, health and safety } \\
\text { risks, animal welfare, fair trade, labour conditions, and human rights } \\
\text { - focuses on consumption as a means of acting in an ethical way towards } \\
\text { particular objects of concern } \\
\text { - extends across various forms of practice, including shopping, investment } \\
\text { decisions, and personal banking and pensions } \\
\text { - any practice of consumption in which explicitly registering commitment } \\
\text { or obligation towards distant or absent others is an important dimension } \\
\text { of the meaning of activity to the actors involved } \\
\text { - a field of marketing, campaigning, and policy-making by which the } \\
\text { ordinary, practical moral dispositions of everyday consumption are } \\
\text { re-articulated by policy-makers, campaigning organisations, and businesses } \\
\text { - close to the idea of "moral selving" (Barnett et al. 2005, pp. 23-35; } \\
\text { Lewis 2011,pp. 1-7) }\end{array}$ \\
\hline
\end{tabular}


Table 1 cnt'd

\begin{tabular}{|l|l|}
\hline \multicolumn{1}{|c|}{ Terms } & \multicolumn{1}{c|}{ Characteristics } \\
\hline Ethical eating \\
or food ethics & - requires the use of foods produced in a humane way, protects the environ- \\
& ment and all those involved in food production and distribution \\
- considers the moral consequences of food choices, both those made by & humans for themselves and those made for food animals \\
- common concerns are: damage to the environment, exploitive labour & practices, food shortages for others, inhumane treatment of food animals, \\
& and the unintended effects of food policy \\
- type of ethical consumption & - solutions include: fair trade, local, organic and slow food (Ethical Eating... \\
& $2010)$ \\
\hline
\end{tabular}

Source: the author's own elaboration.

\section{Defining Ethical Packaging and Discussion}

Ethical packaging may be defined broadly as appropriate packaging. However, that term is difficult to define, as every culture has its own societal norms, beliefs and entrenched values, just as each country has specific natural, environmental and economic conditions. All of that accounts for what is right and wrong in a culture or country. Even various groups of people might understand the scope of ethical packaging in a different way since their knowledge and attitudes are not the same. In their study, P. F. Bone and R. J. Corey reported crucial differences between U.S. ethically interested consumers and practitioners' perceptions of ethical packaging practices (Bone \& Corey 2000, pp. 199-213).

Ethical packaging can be defined as packaging that properly performs its basic functions (to protect, facilitate handling and communicate), its producers having taken into consideration environmental, social, and legal concerns.

The idea of ethical packaging is close to the concept of sustainable packaging. Sustainable packaging is beneficial, safe and healthy for individuals and communities throughout its life cycle and should meet market criteria for performance and cost while sourced, manufactured, transported, and recycled using renewable energy. It also helps individuals perform the five R's: remove, reduce, recycle, renew and re-use (Ojha et al. 2015, pp. 241-245; Brzustewicz 2016, pp. 5-14).

Packaging has a fundamental role in ensuring the safe delivery in good condition of goods throughout supply chains to the end consumers (Lindh, Olsson \& Williams 2016, pp. 3-23). The main functions ethical packaging should effectively and efficiently fulfill along a product's entire supply chain are:

- to protect the product, consumer and the larger environment from toxic and/or unsafe contents, 
- to facilitate handling by enabling convenience, creating utility or service, making retailing, display, transport and storage easy,

- to communicate, inform by promoting, attracting, appealing, enabling (brand) identification and traceability (Lindh et al. 2016, pp. 225-246).

"To contain" is another frequently mentioned packaging function. However, "a container" is a synonym of the noun "package" so this primary function is included in the concept of packaging.

Over $90 \%$ of commodities require packaging, so packaging has great potential to contribute to sustainable development through its functions. Developing packaging with a low negative environmental effect is a strategy pursued in all aspects of packaging. The strategy is not heterogeneous and covers many problems, including: reduced waste and unnecessary packaging, reduced use of resources, minimal use of hazardous substances in packaging and reduced food loss, to name a few. Innovative solutions in packaging, including smart packaging (active and intelligent packaging) and edible packaging contribute to the development of environmentally sustainable packaging (Dobrucka, Cierpiszewski \& Korzeniowski 2015, pp. 7-14).

The survey of Polish students done for this paper shows that consumers' ethical concerns are close to their environmental concerns (Figure 1). In their study on Swedish consumers, H. Lindh, A. Olsson and H. Williams observed the same (Lindh, Olsson \& Williams 2016, pp. 3-23). Over 40 years ago, T. A. Heberlein claimed that attitudes about the environment had shifted from an economic to a moral orientation in the industrialised societies of the West. A number of empirical studies support the claim that attitudes towards the environment in the context of everyday consumer behaviour are morally based (Thogersen 1999, pp. 439-460). The study of consumer choices reported by J. Rokka and L. Uusitalo (Sweden) proves that environmental and ethical concerns are becoming increasingly important in consumers' product choices. J. Rokka and L. Uusitalo, on the other hand, concluded that even the most environmentally conscious consumers do not choose products or services merely on the basis of their environmental aspects, but rather on the trade-off between different aspects (cost, freshness, quality, convenience and so on) (Rokka \& Uusitalo 2008, pp. 516-525). In completing a survey the author conducted among 145 Polish consumers aged 19-78, every third person claimed that "good packaging" should be harmless for the natural environment (Kowalska 2017, pp. 49-57). The increasing environmental concern consumers feel with regard to food products includes product packaging.

However, consumers' perceptions of "what environmentally sustainable packaging is" may differ significantly (Scott \& Vigar-Ellis 2014, pp. 642-649; Young 2008a, pp. 42-48) and most probably depend on their country of origin and socio-demographic characteristics. Another issue involves measuring consumers' 
willingness to pay more for environmentally sustainable packaging. Research covering this issue is sparse. In 2008, S. Young reported that $70 \%$ of US, UK and German consumers and even $80 \%$ of Chinese consumers indicated they were willing to pay more for environmentally friendly packaging (Young 2008a, pp. 42-48; Young 2008b, pp. 24-30). A survey by Tetrapak conducted among 7000 consumers from 13 countries revealed that $47 \%$ of consumers were willing to pay $5 \%$ more for milk packed in environmentally friendly packaging (Consumers... 2013). H. Lindh, A. Olsson and H. Williams concluded in their study based on a survey of 712 Swedish people that $60 \%$ of the consumers surveyed claimed that the environmental impact of packaging played at least a somewhat important role when they chose food products and as many as $86 \%$ of the consumers declared a willingness to pay extra for environmentally sustainable packaging. The point is that a wide variety of consumers were willing to pay very little extra money for environmentally friendly packaging (Lindh, Olsson \& Williams 2016, pp. 3-23).

Ethical packaging must be safe for the environment and all the stakeholders of the packaging supply chain (suppliers delivering packaging materials or packaging, fillers or users, sellers, consumers and end-of-life managers). Meeting standards and packaging laws contributes to the safety of packaging introduced to the market. Adoption of the BRC/IoP (British Retail Consortium/Institute of Packaging) standard by manufacturers of packaging and packaging materials for food and non-food applications may be a means of improving product safety (Global Standard... 2015). This is the only industry standard developed for enterprise operating in the packaging industry. Basic requirements of BRC/ IoP standard are focused on safety, legal and hygienic aspects in the packaging industry (Kawecka 2014, pp. 14-17).

Ethical packaging must meet legal requirements that affect all the stakeholders of the packaging supply chain. Packaging laws most often regulate safety and environmental issues, including waste issues. Food packaging is carefully regulated because the assurance of food safety is a core issue in the European Union. EU Regulations and Polish law address packaging safety, food safety, sufficient inertness, GMP (Good Manufacturing Practices), GHP (Good Hygiene Practices) and HACCP system (Hazard Analysis and Critical Control Points), labelling, traceability of food packaging materials and packaging, environmental protection and waste management, among others (Lisińska-Kuśnierz \& Kawecka 2013, pp. 38-44).

A preventive system in which food safety can be designed into the product and the process by which it is produced, the HACCP system is very effective at controlling hazards (Sperber 2005, pp. 511-514). HACCP is obligatory along the entire food supply chain (excluding primary production) in the EU under Regulation (EC) No 852/2004 on the hygiene of foodstuffs (Regulation (EC) 
No $852 / 2004 \ldots)$. The food packaging industry is excluded from this obligation. However, the principles of HACCP may be applied to existing programs in the industry to create a series of steps ensuring that food safety is maintained throughout the packaging process. The standard has been proven to be effective against accidental contamination and insufficient against deliberate attacks, including fraud (PAS 96:2014 Guide... 2014). The implementation of HACCP should be preceded by the introduction of both GMP and GHP rules (governing the obtainment of raw materials, buildings and production surroundings, machines and devices, washing and disinfection, storage, transport, distribution, staff, training). The focus of GMP and GHP is to ensure health safety of food according to its intended use (Bilska \& Kowalski 2014, pp. 351-361).

It is voluntary, for both consumers and producers, to choose ethical packaging. However, ethical packaging is a response to new consumer trends such as less is more, and it can be used as an essential instrument of green marketing (Dziechciarz-Duda \& Przybysz 2013, p. 51). While more and more consumers become aware of environmental, social, safety and ethical issues, businesses can gain a competitive advantage thanks to ethical packaging.

\section{Survey Results}

To gain a better understanding of the concept of ethical packaging, the author asked her students about their perceptions of ethical packaging. The outcome of the survey is presented in Figure 1.

$62 \%$ of respondents tied ethical concerns to environmental issues in packaging. Most focused on the issues of packaging material and its recyclability. 20\% understand ethical packaging as packaging that is the right size or minimal. Consumers have voiced a desire to see a reduction in the use of unnecessary packaging (Figure 1).

A significant share of the students associated ethical packaging with communication functions, especially proper labelling. Ethical packaging should be properly labelled according to over $40 \%$ of respondents. $15 \%$ of the sample indicated that ethically packaged goods should be labelled in a way that does not offend anybody's culture, beliefs, race, sexual or political orientation, while another $10 \%$ believed packaging should use polite words. $14 \%$ said ethical packaging should enable the fast identification of a product, while 13\% said it should be clear. About $40 \%$ of the respondents indicated that ethical packaging should be functional, ergonomic and/or simple.

More than a dozen of the students pointed to the protective function of ethical packaging. $24 \%$ said that ethical packaging is safe for consumers and another $15 \%$ 


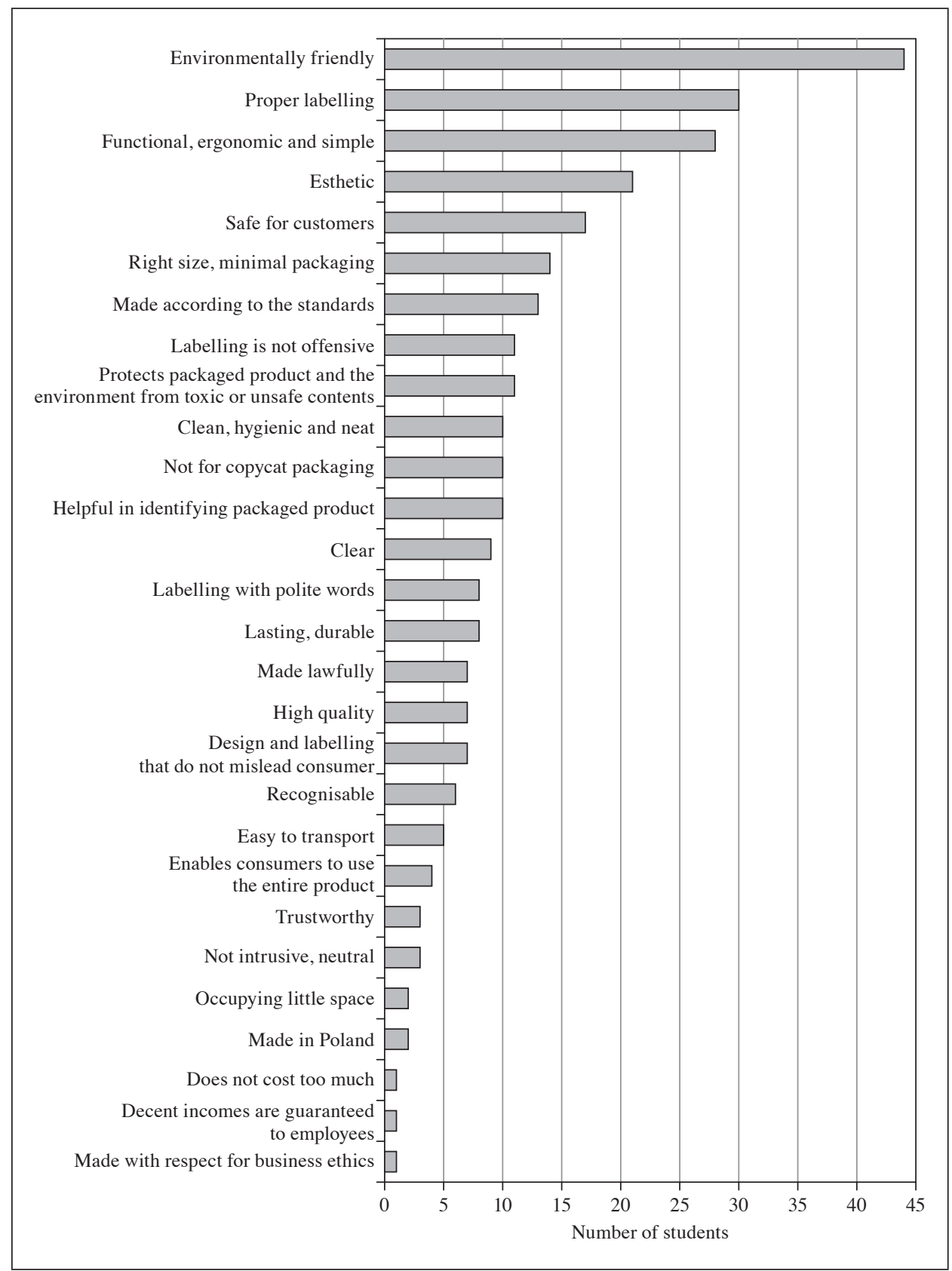

Fig. 1. Polish Students' Understanding of Ethical Packaging

Source: the author's own survey. 
that it protects its content through their journey along the supply chain from filling to consumption and protects the surroundings from products that are potentially hazardous to the environment.

Almost $30 \%$ of the respondents think that ethical packaging should be aesthetic. A dozen or more respondents associated ethical packaging with obeying the law, common standards and hygienic rules. Several students claim that ethical packaging should be high quality, lasting and durable, easy to transport and take up little space, be trustworthy, not intrusive but recognisable, and be produced by a local enterprise (made in Poland).

While the students had a general sense of ethics and business ethics, most had never studied packaging problems, mainly because they have not attended a course covering packaging problems. However, their understanding of ethical packaging seems to be in line with trends of recent years.

\section{Summary}

A number of studies suggest that environmental and ethical concerns are becoming increasingly important for consumers' product choices, including packaging. Ethical behaviour, moral, emotional and social competences of the owners, managers and employees of any organisation seem to be a prerequisite for holding a competitive advantage in the long run. Crisis situations based on environmental, social and political issues are more and more frequently emerging in the marketplace. Therefore, ethical attitudes have become an issue. A review of the recent literature shows the importance of numerous concepts related to ethical behaviour in business, such as business ethics, corporate ethics, CSR, TBL, ethical consumption, ethical eating, ethical packaging and sustainable packaging.

Consumers' perception of ethical packaging is close to their understanding of sustainable packaging. A survey of Polish students done for this paper and recent literature confirm the main hypothesis and provide evidence of the priority of environmental concerns regarding the idea of ethical packaging. Other aspects of ethical packaging frequently mentioned by those who took the survey include: proper labelling, functionality and safety. These may be added to the main functions of packaging, which are to protect, facilitate handling and communicate. Given the legal, environmental and social concerns, including safety issues, it would seem inevitable that ethical packaging will become more widely used. 


\section{Bibliography}

Barnett C., Cloke P., Clarke N., Malpass A. (2005), Consuming Ethics: Articulating the Subjects and Spaces of Ethical Consumption. Antipode, "A Radical Journal of Geography", vol. 37, no 1, https://doi.org/10.1111/j.0066-4812.2005.00472.x.

Bilska A., Kowalski R. (2014), Food Quality and Safety Management, "LogForum”, no $10(3)$.

Bone P. F., Corey R. J. (2000), Packaging Ethics: Perceptual Differences among Packaging Professionals, Brand Managers and Ethically-interested Consumers, "Journal of Business Ethics", vol. 24, no 3, https://doi.org/10.1023/A:1006257523743.

Brzustewicz P. (2016), The Application of Eco-compass Method in Sustainable Product Development, "Acta Scientiarum Polonorum. Oeconomia", no 15(1).

Cambra-Fierro J., Hart S., Polo-Redondo Y. (2008), Environmental Respect: Ethics or Simply Business? A Study in The Small and Medium Enterprise (SME) Context, "Journal of Business Ethics", vol. 82, no 3, https://doi.org/10.1007/s10551-007-9583-1.

Chwistecka-Dudek H. (2014), Koncepcja etyki w procesach zarzq̨dzania przedsiębiorstwem, Wyższa Szkoła Biznesu w Dąbrowie Górniczej, Dąbrowa Górnicza.

Consumers Willing to Pay More for Environmentally Friendly Packaging (2013), Tetrapak, http://www.summer-foundation.org/en/News/Archive/Consumers-willing-to-pay-more-for-environmentally-friendly-packaging (accessed: 5.05.2017).

Dobrucka R., Cierpiszewski R., Korzeniowski A. (2015), Intelligent Food Packaging Research and Development, "LogForum", no 11(1), https://doi.org/10.17270/ J.LOG.2015.1.1.

Dziechciarz-Duda M., Przybysz K. (2013), Odpowiedzialny biznes jako nowy kierunek $w$ marketingu przedsiębiorstw, "Zeszyty Naukowe Uniwersytetu Ekonomicznego w Krakowie", nr 909.

Elkington J. (1997), Cannibals with Forks: The Triple Bottom Line of Twenty-First Century Business, Capstone Publishing Ltd, Oxford.

Ethical Eating. Food and Environmental Justice 2008-2012 (2010), Unitarian Universalist Association, http://www.uua.org/sites/live-new.uua.org/files/documents/washingtonoffice/ethicaleating/studyguide.pdf (accessed: 1.03.2016).

Global Standard for Packaging and Packaging Materials. Issue 5 (2015), BRC/IOP, http://www.brcglobalstandards.com/Manufacturers/Packaging/PackagingIssue5.aspx\#. VuKJ4dCKSod (accessed: 11.03.2016).

Kawecka A. (2014), BRC/IoP Standard Importance in Packaging Quality Assurance, "Production Engineering Archives", vol. 4, no 3.

Kowalska A. (2017), Analysis of Consumers' Expectations towards Packaging for Fast-moving Consumer Goods, "Polish Journal of Commodity Science", no 1(50).

Lewis T. (2011), The Ethical Turn in Commodity Culture: Consumption, Care and the Other, "A Journal of Literature, Culture and Literary Translation", no 2(1), http:// dx.doi.org/10.15291/sic/2.1.lc.12.

Lindh H., Olsson A., Williams H. (2016), Consumer Perceptions of Food Packaging: Contributing to or Counteracting Environmentally Sustainable Development, "Packaging Technology and Science", vol. 29, no 1, https://doi.org/10.1002/pts.2184.

Lindh H., Williams H., Olsson A., Wikström F. (2016), Elucidating the Indirect Contributions of Packaging to Sustainable Development: A Terminology of Packaging 
Functions and Features, "Packaging Technology and Science”, vol. 29, no 4-5, https:// doi.org/10.1002/pts.2197.

Lisińska-Kuśnierz M., Kawecka A. (2013), The Role of Packaging Supply Chain in Food Packaging Safety Assurance, "Logistics and Transport", vol. 19, no 3.

Medeiros de J. F., Ribeiro J. L. D., Cortimiglia M. N. (2014), Success Factors for Environmentally Sustainable Product Innovation: A Systematic Literature Review, "Journal of Cleaner Production", vol. 65, https://doi.org/10.1016/j.jclepro.2013.08.035.

Mroziewski M. (2014), Etyka $w$ zarzqdzaniu. Wybrane problemy w aspekcie inteligencji moralnej i konkurencyjności przedsiębiorstwa, Uniwersytet Warmińsko-Mazurski w Olsztynie, Olsztyn.

Ojha A., Sharma A., Sihag M., Ojha S. (2015), Food Packaging - Materials and Sustainability - A Review, "Agricultural Reviews", vol. 36(3), https://doi.org/10.5958/09760741.2015.00028.8.

PAS 96:2014 Guide to Protecting and Defending Food and Drink from Deliberate Attack (2014), The British Standards Institution, http://www.food.gov.uk/sites/default/files/ pas96-2014-food-drink-protection-guide.pdf (accessed: 10.02.2016).

Promoting a European Framework for Corporate Social Responsibility. Green Paper (2001), European Commission, Office for Official Publications of the European Communities, Luxembourg.

Regulation (EC) No 852/2004 of the European Parliament and the Council of 29 April 2004 on the hygiene of foodstuffs, Official Journal of the European Union L 139, 30.4.2004, as amended.

Rokka J., Uusitalo L. (2008), Preference for Green Packaging in Consumer Product Choices - Do Consumer Care?, "International Journal of Consumer Studies", vol. 32, no 5, https://doi.org/10.1111/j.1470-6431.2008.00710.x.

Scott L., Vigar-Ellis D. (2014), Consumer Understanding, Perceptions and Behaviours with Regard to Environmentally Friendly Packaging in a Developing Nation, "International Journal of Consumer Studies", vol. 38, no 6, https://doi.org/10.1111/ijcs.12136.

Soroka A., Mazurek-Kusiak A. (2014), The Importance of Corporate Social Responsibility of Enterprises in Business, "Acta Scientiarum Polonorum. Oeconomia", no 13(2).

Sperber W. H. (2005), HACCP Does not Work from Farm to Table, "Food Control", vol. 16, no 6, https://doi.org/10.1016/j.foodcont.2003.10.013.

Steinmann H., Scherer A. G. (2000), Corporate Ethics and Management Theory [in:] Contemporary Economic Ethics and Business Ethics, ed. P. Koslowski, Springer, Berlin, Heidelberg.

Thogersen J. (1999), The Ethical Consumer. Moral Norms and Packaging Choice, "Journal of Consumer Policy", vol. 22, no 4, https://doi.org/10.1023/A:1006225711603.

Young S. (2008a), Packaging and the Eenvironment: A Cross-cultural Perspective, "Design Management Review", vol. 19, no 4, https://doi.org/10.1111/j.1948-7169.2008. tb00140.x.

Young S. (2008b), Packaging and the Environment: the Shoppers' Perspective, "Brand Packaging", vol. 12(1). 


\section{Etyczne opakowanie - analiza wstępna}

(Streszczenie)

Artykuł jest wynikiem wstępnych badań dotyczących zagadnienia etycznego opakowania. Jego celem jest zdefiniowanie pojęcia etycznego opakowania i uporządkowanie pojęć związanych z etycznym postępowaniem uczestników rynku. Przegląd literatury z zakresu etyki i opakowalnictwa umożliwił zestawienie definicji takich pojęć, jak: etyka biznesu, etyka korporacyjna, społeczna odpowiedzialność biznesu, potrójna linia przewodnia, etyczna konsumpcja, etyczne jedzenie i zrównoważone opakowanie, oraz stanowił podstawę dalszych analiz i dyskusji. Aby sprawdzić, jak rozumiana jest koncepcja etycznego opakowania, w 2016 r. przeprowadzono badania wśród 71 studentów Uniwersytetu Marii Curie-Skłodowskiej w Lublinie. Wyniki badań stanowią głos w dyskusji na temat postrzegania etycznego opakowania przez konsumentów.

Słowa kluczowe: etyczne opakowanie, zrównoważone opakowanie, funkcje opakowania, społeczna odpowiedzialność biznesu, etyczna konsumpcja, etyczne jedzenie. 